\title{
Institutions, Property Rights, and Economic Development in Historical Perspective
}

\author{
Luis Angeles*
}

February 9, 2011

\begin{abstract}
Institutions, and more specifically private property rights, have come to be seen as a major determinant of long-run economic development. We evaluate the case for property rights as an explanatory factor of the Industrial Revolution and derive some lessons for the analysis of developing countries today. We pay particular attention to the role of property rights in the accumulation of physical capital and the production of new ideas. The evidence that we review from the economic history literature does not support the institutional thesis.
\end{abstract}

Keywords: Institutions and Economic Development; Property Rights; Industrial Revolution; long-run growth.

JEL classification: O43; O34; N33.

\section{Introduction}

Economists' thinking of the growth process has shifted its focus of attention more than once over time. From Adam Smith's classical thesis emphasizing the division of labour and the extent of the market, economists have put

${ }^{*}$ Economics, University of Glasgow. Adam Smith Building, Glasgow G12 8RT, United Kingdom. Email: luis.angeles@glasgow.ac.uk . Tel: +44 141330 8517. I thank seminar participants at University Carlos III (Madrid) for helpful comments, all remaining errors are mine. Financial support from the Carnegie Trust for the Universities of Scotland is gratefully acknowledged. 
forward the role of physical and human capital accumulation, technological progress, and - more and more nowadays - institutions.

The current interest in the role of institutions derives from the inability of the research programme of Solow (1956), Romer $(1986,1990)$ and followers to uncover the "deeper" determinants of economic growth. Neoclassical and endogenous growth theories provide a transparent - if somewhat mechanistic - explanation of how capital and ideas are accumulated and produce higher output. But if stocks of capital and ideas can be accumulated following the processes described by these theories the obvious question is why this accumulation is not taking place everywhere in the world and since the dawn of history. That's where institutions come in.

The current conception of institutions and how they affect economic growth is derived to a large extent from the work of Douglass C. North. North's best metaphor is perhaps that institutions are "the rules of the game" of a society (North 1990). What is meant by this is that institutions establish the constraints, determine the costs and benefits, under which individuals take their economic decisions. Why do so many countries fail to develop? Because their institutions are such that individuals do not find it profitable to invest in physical capital, human capital, and new ideas.

North has gone to great lengths to build the case for the importance of institutions in theoretical terms (North 1981, 1990, 2005) and has interpreted the evolution of early modern Europe from that theoretical perspective (North and Thomas 1973, North 1981, North and Weingast 1989). The last decade has seen the development of a considerable empirical literature aiming to show that institutions are "a fundamental cause of long-run growth" (Acemoglu et al. 2005). ${ }^{1}$ Today the idea that institutions are one of the central factors explaining the Industrial Revolution and the differences

\footnotetext{
${ }^{1}$ Acemoglu et al. $(2001,2002)$ are the seminal contributions in this literature; but see also Knack and Keefer (1995), Hall and Jones (1999), Easterly and Levine (2003), Rodrik et al. (2004) and Feyrer and Sacerdote (2009). For a comparison of many of these papers see Hansson (2009). For dissenting views see Glaeser et al. (2004) and Angeles (2010).
} 
in economic development around the world is widely accepted in academic and policy circles.

The problem of endogeneity in the empirical literature is always recognized but never fully solved (institutions cause development but development also causes institutions). The literature has favored the use of IV regressions where geographic and historically-determined variables play the role of instruments. While highly suggestive, the conclusions of this empirical literature can always be questioned for its dependence on the assumptions underlying IV estimation. Indeed, geographic and historically-determined variables may well influence long-run growth through channels other than institutional development. ${ }^{2}$

Because of the above caveat, the present paper takes an alternative route to study the question. We focus on the most paradigmatic example of growth-enhancing institutions: the protection of private property rights. We then consult the economic history literature for evidence of the role of property rights as a major driver of the Industrial Revolution through their purported effects on the accumulation of capital and ideas. Most of our discussion is empirical, but we will pay attention to the theoretical case for the importance of property rights whenever we find it lacking. Although we focus on pre-industrial Europe, we believe that important lessons can be learned for the analysis of developing countries today. Accordingly, we extend some of our discussions in that direction.

We close this introduction by noting that the ongoing discussion of the role of institutions on economic development is not purely academic but has large implications for policy making. As Adam Przeworski has put it, the results from this literature can be used to justify "institutional engineering"

\footnotetext{
${ }^{2}$ For instance, while Acemoglu et al. (2001) stress that geography and history determined the degree of European settlement and that European settlers brought their institutions with them, Glaeser et al. (2004) retort that European settlers brought many other things with them - starting with their own human capital. For additional works on the consequences of European settlement see Angeles (2007) and Angeles and Neanidis $(2009,2010)$. For a discussion of the endogeneity issues in the institutional literature see Paldam and Gundlach (2008).
} 
(Przeworski 2004); whereby developing countries' institutions would try to be modelled in the image of those from developed nations. Before advocating such a large-scale experiment, economist have the duty to subject their hypotheses to as many different types of falsification attempts as possible. Looking at the historical record appears to be as good a verification strategy as any other we can think of.

\section{Institutions}

"Institutions" is a dangerous word; its meaning is not immediately evident and will change according to the context and the academic discipline where it's being used. In economics, the most influential theoreticians of the role of institutions have pioneered universal and overarching definitions of them. Thus, Douglass North:

Institutions are the humanly devised constraints that structure political, economic and social interaction. They consist of both informal constraints (sanctions, taboos, customs, traditions, and codes of conduct), and formal rules (constitutions, laws, property rights).

North (1990, p. 97)

And similarly, Avner Greif:

An institution is a system of rules, beliefs, norms and organizations that together generate a regularity of (social) behavior.

Greif (2006, p. 30)

A problem with definitions such as the above ones is that they are too broad for meaningful empirical testing. A theory of the importance of institutions that uses such an all-encompassing definition of them falls dangerously close of unfalsifiability. It is hard to think of any human society in which some type of humanly devised constraint - be it cultural norms, religious beliefs, formal laws or commonly-held values - would not have a 
significant influence on its members. There is, after all, not much left outside such a definition to influence human actions.

The empirical literature has been swift to abandon the intellectual heights of the above definitions for more mundane - and empirically meaningful concepts of institutions. Right from the start, the one concrete institutional element on which all authors agree as a major determinant of economic development is the existence of secure property rights. Thus, when Douglass North decides to advance the English Glorious Revolution as a prime example of institutional development leading to the Industrial Revolution, he casts most of the discussion in terms of property rights (North and Weingast 1989). And most of the empirical literature on the subject, starting with the influential work of Acemoglu et al (2001), have used measures of institutions that invariably relate to the security of property rights (like the

"risk of expropriation" from Political Risk Services or the "constraints on the executive" from the Polity IV dataset). Accordingly, this paper will focus on the role of property rights on long-run economic development.

\section{Property Rights}

The logic linking property rights to economic development is easy to grasp: people who invest in new capital or -in the case of intellectual property rights- new ideas expect to have the freedom to use and profit from them as they see fit. If that condition is not met, if people believe that their capital may be expropriated or their ideas stolen, they will refrain from making those investments in the first place. "The more likely it is that the sovereign will alter property rights for his or her own benefit, the lower the expected returns from investment and the lower in turn the incentive to invest" (North and Weingast 1989, p. 803).

Property rights fit neatly into the neoclassical and endogenous growth literatures that constitute our core understanding of the mechanics of economic growth. These literatures explain how investments in capital and ideas turn the wheels of economic growth. If weak property rights lead to 
low levels of investment the consequences for growth can be readily understood.

In order to organize our thoughts it is useful to remain grounded in modern growth theory and analyze how property rights may affect the accumulation of the two main factors entering an aggregate production function: capital and ideas. Regarding the links between property rights and capital accumulation, our discussion will be focused on physical capita and land - a major factor of production in pre-industrial times. We do not stress the effects on human capital because the influence of property rights on its accumulation is likely to be mainly indirect.

Indeed, human capital differs from physical capital and land in that it cannot be expropriated or taken away from its owner. The knowledge that an engineer acquires through his studies cannot be extracted and used by someone else in the same way that a piece of machinery or a tract of land can. Human capital cannot be seized, and something that cannot be seized has no need for protection. Of course, it is still possible to take away the product of human capital - notably through taxes. Taxes will be discussed in the next section and the discussion can be understood as applying to the product of all kinds of capital. We may note here, however, that most pre-industrial taxes bore little or no relationship to stocks of human capital. An example of a tax that correlates well with levels of human capital is the income tax, but its first introduction in Britain in 1799 postdates the Industrial Revolution.

On the other hand, human capital accumulation may very well be affected indirectly by the absence of property rights for other factors of production. Indeed, human capital may be more useful when combined with physical capital and ideas. In consequence, we do not disregard the effects of property rights on human capital accumulation but, by pointing out that the effect will mainly work through indirect channels we can justify focusing on the direct effects on physical capital and ideas. We turn to these in what follows. 


\section{Property Rights and Capital Accumulation}

The most immediate effect of weak property rights should be on the accumulation of physical capital. We can easily imagine an entrepreneur deciding whether to invest in a new project by calculating its expected profit. The probability of having his capital expropriated by the government would surely enter his calculations and potentially deter him from investing.

The theoretical case outlined above is sound and we have nothing to add to it. An argument, however, may well be theoretically sound and empirically irrelevant. Improvements in property rights are a logically-consistent potential explanation for the Industrial Revolution. To be a true explanation, however, it must be verified against the empirical record. Was preindustrial Europe a region of poor or inexistent property rights and was an improvement in these rights what lead to its eventual take-off? The case for that view has been made by North and Weingast (1989), and the conclusions of their influential analysis can be found in subsequent parts of the literature such as Acemoglu et al. (2005) or Olson (2000). ${ }^{3}$ As it turns out, however, much of the evidence available elsewhere in the economic history literature points to a different conclusion.

Although capital can be taken away from its rightful owner by the government or by other individuals, most of the literature has focused on the government as the expropriator-in-chief. ${ }^{4}$ Grant that the government can take away private capital mainly in two ways: taxes and outright expropriation. If the value of capital is the sum of all actualized future profits accruing to its owner then taxes, which redirect a share of those profits

\footnotetext{
$3 " \ldots$ after 1688, the greater security of property rights in England led to a huge expansion of financial institutions and markets which, North and Weingast (1989) argue, laid the institutional foundations for the industrial revolution" (Acemoglu et al. 2005, p. 456-457). "Individual rights to property and contract enforcement were probably more secure in Britain after 1689 than anywhere else, and it was in Britain, not very long after the Glorious Revolution, that the Industrial Revolution began" (Olson 2000, p. 38).

${ }^{4}$ This is justifiable since expropriation by other individuals, what we call crime and robbery, has always been present throughout the world and simply requires the use of some ressources in the form of guards and security systems.
} 
to the government, are nothing more than partial expropriation (we are of course overlooking the public goods that those taxes would fund). It follows that to evaluate the claim that property rights were hindering growth in preindustrial Europe we need to look at the level of taxes and the occurrence of expropriation.

\subsection{Capital and taxes}

On the subject of taxes there should not be two opinions. Throughout preindustrial Europe low taxes were the norm given the significant limits on state capacity. England, for instance, was characterized by very low taxes from the thirteen century until the Glorious Revolution: around $2 \%$ or less of national income if we count only the central government and up to $6 \%$ of national income if we include the church (Clark 2007, p. 148-154). These

numbers were typical not just in Europe but around the world. What's more surprising, once Parliament got the upper hand over the English crown in the setting of new taxes the consequence was more, not less taxes. From 1688 onwards we see the government's share in aggregate output increasing to levels never seen before (around $20 \%$ of national income by the end of the 18th century). From the perspective of tax policy at least, it is difficult to argue that incentives to capital accumulation were poor during the middle ages or that they improved during the 18th century.

Furthermore, recent research has revealed that higher taxes in societies with a more constrained executive branch is not an English exception but a general characteristic of Europe at least since the mid-17th century. This is the conclusion reached by Dincecco (2009) after constructing a panel dataset of per capita taxes in early modern Europe. Regression analysis shows that taxes tend to be about $60 \%$ higher in countries with a limited government, even after controlling for wars, domestic conflicts and rates of urbanization. Thus, the buildup to the Industrial Revolution was characterized by more, not less, taxes.

It was not that kings were not interested in higher taxes, but they simply 
did not have enough power to unilaterally impose their wishes. The clearest example of this is England, were we observe attempts to increase taxation being stopped by the nobility as early as 1215 (The Magna Carta) and by the peasantry as early as 1381 (The Peasant's Revolt). As best reflected in John Hampden's statement when refusing to pay a tax that Charles I was trying to impose without the approval of Parliament, "What an English King has no right to demand, an English subject has a right to refuse" ${ }^{5}$.

\subsection{Capital and expropriation}

Let us then turn our attention to the occurrence of unilateral expropriation in pre-industrial Europe. One can, of course, find examples. Henry VIII expropriated church lands and assets en masse during the so-called Dissolution of the Monasteries, 1536-1541. Edward I expelled all Jews from England in 1290 and duly expropriated their possessions. Note, however, that in the two examples given above the victim was a particular social group that had fallen in disfavor and could not defend itself. The Catholic church was under retreat in northern Europe during the Reformation of the 16th century, and land confiscations had taken place in Sweden (1527), Denmark (1528) and the Swiss cities of Zurich, Basel and Geneva. And the expulsion and expropriation of Jews, sadly, was a recurrent theme in European history since the Middle Ages. The point is that expropriation was an exceptional measure used only in exceptional circumstances. English kings could not expropriate whoever they wanted whenever they wanted, and centuries of law and tradition supported the nobility in their rights to property. Clear evidence of this can be seen in the decision of some of England's most powerful monarchs, such as Elizabeth I or James I, to sell part of their lands in order to finance war efforts. Clearly, expropriating landowners was not a feasible policy.

Our best hope to quantify the degree of property right protection in preindustrial Europe is to look at interest rates or rates of return on private capital. A world in which capital investments are permanently subject to

\footnotetext{
${ }^{5}$ This quote is found in several places but its original source is not given. You can find it, for instance, in John Hampden Society (2009).
} 
unilateral expropriation would be characterized by high rates of return to compensate investors for the risk incurred. Note that it is interest rates on private debt that matter here. The point is of importance because North and Weingast's (1989) sole evidence on the improvement in England's institutions after 1688 is the falling rates on public debt. Interest rates on public debt tell us about the reliability of the state as a debtor; but say nothing about the security of private property rights. If anything, falling interest rates on public debt could denote that the state can pay its debts easily by expropriating its subjects.

As it turns out, research has shown that rates of return on private capital have been quite low in England since the late 14th century (Epstein 2000, p. 62; Clark 2007, p. 167-169) and that their slowly decreasing trend suffered no notable alteration following the Glorious Revolution (Clark 1996, Quinn 2001). The Glorious Revolution may have mattered a lot for government finances, but it had no effect on the (already secure) private property rights. Private capital was rewarded in England at the tone of $5 \%$ per year since the mid-1400s, a rate quite in line with those observed on similar types of investments nowadays. ${ }^{6}$ If the rate of return on private capital is a good indicator of the risk of expropriation then this risk has not changed much in England between the Renaissance and our times.

What we have said for England is also true for Western Europe. Epstein (2000, 2005) and van Zanden (2009) have shown that the most significant decrease in private rates of return in Europe occurred during the 14th century, probably following the Black Death, when rates fell from around 10-11\% to about $7 \%$. Rates continued to fall gently afterwards, but Europe can be characterized as a continent of moderate rates of return on private capital for

\footnotetext{
${ }^{6}$ The comparison with current rates of return ought to be made in real terms. Inflation was nerly zero in pre-industrial times, so the figure of $5 \%$ can be taken as the real rate of return for pre-industrial times. It refers to investments in land and housing (Clark 2007). Real rates of return for the 20th century have been reported by Campbell et al. (2001). For the period 1926-1998 they have averaged $7.4 \%$ for US stocks and $2.2 \%$ for US government bonds. The risk of investments in land and housing may be placed in between that of stocks and government bonds, which implies that the figure of $5 \%$ from pre-industrial times is roughly what we would expect today.
} 
about 400 years before the Industrial Revolution. Moreover, Epstein (2000, 2005) and Homer (1963) clearly show that England was not exceptional in the European context. In fact, if interest rates on private debt are a guide to the security of property rights the institutional view should have focused on the city-states of Northern Italy and on the Dutch Republic as the logical birthplace of the Industrial Revolution. English rates did not become low by European standards until the 18th century - while still remaining higher than Dutch rates (Homer 1963).

But the indirect evidence provided by rates of return on private capital is not the only reason to believe that private property rights were secure in pre-industrial Europe. Direct evidence can be found by noting that private investors were eager to take advantage of new investment opportunities, and that the capital stock of pre-industrial economies was far from being static. We illustrate this below with two examples, which demonstrate the responsiveness of capital investments to new market developments many centuries before the Industrial Revolution.

A first example is the spread of the printing press. The printing press constitutes an ideal case study since its invention (in Europe) is tied to a specific time and place: Mainz, Germany, in the 1440s (the Gutenberg Bible was printed sometime between 1452 and 1454). In what constitutes a remarkable case of private capital responding to new investment opportunities, by 1500 printing presses were found in 205 European cities from Portugal to Poland and everywhere in between. ${ }^{7}$ A printing press represented a major capital investment: a complete set would cost the equivalent of 4 to 10 years worth of a craftsman's wages. Capital financing by banks or wealthy individuals was therefore essential, and this would not take place without relatively secure property rights.

A second example can be found in what is perhaps the most important form of industrial capital in the European Middle Ages: the mills. Mills

\footnotetext{
${ }^{7}$ Dittmar (2010). For the effects of the printing press on book production and book prices see Van Zanden (2009, chapter 6).
} 
were expensive to build, Langdon (2004, p.179) estimates the cost of English watermills during the 14 th and 15 th centuries as at least $£ 20$ and as much as $£ 100$ or more. Yet mills were ubiquitous in England: 6,082 of them could be found in the year 1086 according to the Domesday Book. The maintenance of this capital stock required very significant investments that could not be compatible with insecure property rights. A medieval mill lost about $10 \%$ of its total value each year to depreciation (Langdon 2004, p.180), so the English private sector had to build the equivalent of 608 new mills each year merely to maintain its productive capacity.

Thus, private investment in pre-industrial Europe does not give the impression of being heavily restricted by insecure property rights. At any rate, the risk of expropriation was not important enough to deter investors from committing large sums of money over long periods of time in the construction of mills or printing presses.

\subsection{What do episodes of sovereign debt default tell us?}

As it turns out, the one area where something akin to outright expropriation by European monarchs can be observed with some regularity is in the many episodes of sovereign debt default. Reinhart and Rogoff (2009) have documented as many as 20 instances of sovereign default on external debt in Europe before the 19th century (the number would be larger if we add defaults on domestic debt). Douglass North has interpreted these events as evidence of the insecurity of property rights: "The Crown's inability to honor its contractual agreements for borrowed funds is a visible indicator of its readiness to alter the rights of private parties in its own favor" (North and Weingast 1989, p. 810).

We would argue, however, that episodes of sovereign debt default are better seen as evidence of the monarch's weaknesses - not of his strength. Kings built up debts precisely because they were unable to tap into alternative sources of financing such as outright expropriation of their subjects' 
assets or unilateral increases in taxation. As an example, the debt default of Philip II of Spain in 1575 was prompted by the refusal from the Spanish Cortes to raise the sales taxes as the king demanded (Drelichman and Voth, forthcoming). Not only that, but kings were forced into long and acrimonious negotiations with their creditors; in a manner that reminds the negotiations between today's developing countries with the IMF. When Philip II suspended payments on its debt in 1575, his Genoese bankers penalized him by imposing an embargo on all currency transfers between the crown and its troops waging war in the Netherlands. The unpaid army mutinied and sacked the Spanish-loyal city of Antwerp on 4 November 1576, in a cruel episode that passed into history books as the Spanish Fury. As a result, the loyalist provinces of the Low Countries united with the rebellious Holland and Zeeland for the purpose of expelling the Spanish army. This was a costly loss for Philip II, who was forced to reach an agreement with his bankers and pay his arrears (Conklin 1998). Kings, at any rate in pre-industrial Europe, were much less powerful than is sometimes assumed.

Moreover, interpreting the occurrence of sovereign debt defaults as cases of capital expropriation misses one essential point: the fact that interest rates on public debt were very high during this period precisely to compensate lenders for the risk of default. In other words, lenders were receiving on average a fair return for their money - even when we take into account payment delays and interruptions. The ex-post real rate of return of Genoese lending to the crown of Spain has been estimated to be between 8 and 14\%; a handsome premium for the risk incurred ${ }^{8}$. And the interest rate on English public debt was $14 \%$ in the early 1690s (North and Weingast 1989, p. 823) which, if we assume a probability of total default of $5 \%$ per year i.e. one default episode every 20 years, would still leave an ex-post rate of return of $9 \%$.

To summarize, the available evidence contradicts the idea of a preindustrial Europe of all-powerful monarchs and indiscriminate expropriation.

\footnotetext{
${ }^{8}$ Cited in Conklin (1998, p. 492). See Drelichman and Voth (forthcoming) for more recent calculations.
} 
Instead, we see a picture where private capital was remunerated modestly, investment took place regularly, and kings were forced into debt by their inability to raise taxes unilaterally or expropriate their subjects.

\subsection{Developing countries today}

Turning to the case of developing countries today, the evidence for weak property rights appears to be more solid. That, at least, is what the measures of property rights protection most commonly used in the literature show. PRS' "risk of expropriation" or Polity IV's "executive constraints", for instance, show a clear correlation with levels of GDP per capita of between 0.70 and 0.80 . But this apparently strong evidence may be criticized on at least two accounts.

First, most popular measures of property right protection - including those mentioned above - are the outcome of opinion surveys of business people or experts' assessments. In other words, they are bound to be heavily influenced by the image of developing countries in the world. As noted by Glaeser et al. (2004), measures of institutional quality that do not rely on subjective assessments show small or no correlation with GDP per capita. For instance, variables measuring the permanence in office of supreme court judges and the extent of judicial review of legislation have a correlation with GDP per capita of 0.03 and 0.06 respectively (not statistically different from zero in both cases).

A second and related point is that most popular measures used in the literature are focused on the property rights of international investors. To a large extent this is inevitable since the assessment of business people or experts will necessarily be based on the cases and events they know best, which naturally tend to be those of international investors suffering from nationalization or outright expropriation. While such cases are real enough, they should not be considered as representative of the overall regime of property protection in the country. 
Nationalizations of international companies, particularly in extractive industries such as oil or mining, have occurred with some regularity throughout the developing world. ${ }^{9}$ There are usually big political rewards and quite limited risks of pursuing such nationalization policies. Foreign firms are ideal scapegoats for the ills of a nation, and left-leaning governments have had little difficulty portraying them as the vanguard of (American, British, French) imperialism. Periods of high commodity prices lead to huge profits for the foreign companies, giving the obvious impression that these are robbing the country of its wealth. The great majority of the population would support the measure as a matter of principle, while the local elite would hope to benefit from it by inheriting the control of the nationalized firms. The only risk would be the reaction from foreign governments, which in any case would have no effect on the government's control of the country.

Nationalizing domestic firms is a different proposition altogether since it carries major political risks by antagonizing domestic forces. Just as kings in pre-industrial Europe, third-world governments are rarely in such a strong position that they can risk a battle with the local elite. Accordingly, examples of nationalization of domestic firms are rather rare and are concentrated in extreme episodes such as the 1917 communist takeover in Russia. For most developing countries today the risk of expropriation of domestic firms appears to be very different and much lower than the risk facing foreign firms in extractive industries.

If instead of relying on the measures used in the literature we look at one of the magnitudes that guided our discussion of pre-industrial Europe, the real interest rate, we see a different picture. Figure 1 plots the average real interest rate over the period 1980-2008 against the log of GDP per capita for 169 developed and developing countries ${ }^{10}$. It is apparent that

\footnotetext{
${ }^{9}$ To name some salient examples, Mexico nationalized its oil industry in 1938, Iran did the same in 1951, Chile nationalized its copper mines in 1971, Venezuela its oil industry in 1976, Bolivia its tin mines in 1952 and its gas industry in 2006.

${ }^{10}$ Source: World Bank (2009). The real interest rate is defined as the lending interest rate adjusted for inflation as measured by the GDP deflator. The average is taken over all available observations over the period 1980-2008, which for some countries is considerable
} 
no relationship exists between the two variables, belying the idea that real rates tend to be higher in poorer countries. The result can be confirmed by a linear regression showing no statistically significant relationship between real interest rates and GDP per capita. If real interest rates provide an overall assessment of the risk of expropriation to domestic firms then figure 1 suggest that expropriation in developing countries may be much less prevalent than commonly thought.

A final point is in order to lead us into the next section. The emphasis that much of the literature puts on property rights and capital accumulation sits uncomfortably besides a central tenet of economic growth theory: that growth, in the long run, is essentially a matter of technological progress. Growth due to capital accumulation would run into decreasing returns and stall in the absence of technological progress; just imagine how much would pre-industrial agriculture have progressed through an endless accumulation of ploughs and hoes and no invention of synthetic fertilizer and tractors. Thus, the explanation for the Industrial Revolution and the differences between poor and rich countries should be sought in the process of creating and adopting new technology and, according to the institutional view, in the presence or absence of intellectual property rights. ${ }^{11}$

\section{Property Rights and Ideas: Intellectual Prop- erty Rights}

Contrary to the preceding section, the case for the relationship between property rights and the production of new ideas may be challenged both on the theoretical and on the empirical side - and we turn to each type of argument in what follows.

less than the maximum of 29 observations.

${ }^{11}$ A large part of the empirical growth literature, what is known as "development accounting", has also underscored the primacy of technology over capital accumulation. Caselli (2005) summarizes the state of this literature and offers some insightful extensions. 


\subsection{Theoretical considerations}

Intellectual property rights (IPRs) give the creator of an idea certain exclusive rights over its creation; notably the right to benefit from its commercial exploitation through a legal monopoly. These rights take mainly the form of patents and copyrights. ${ }^{12}$ The theoretical case for intellectual property protection relies on the argument that making the invention of new ideas more profitable should have a positive effect on their production. In fact, standard economic modelling turns intellectual property rights into an absolute necessity by assuming that ideas are non-rival and that perfect competition characterizes product markets. If ideas are non-rival they can be reproduced by anyone at zero cost, meaning that profits would disappear under perfect competition. Thus, innovators will not be able to recover their $\mathrm{R} \& \mathrm{D}$ costs and would not engage in the production of new ideas in the first place, unless they are given some market power.

This theoretical picture, however, is at odds with reality. While the abstract concept of an idea may be non-rival, understanding it and finding an economic use for it require investments that are far from negligible. Take the ideas of Quantum mechanics, freely available at your local university library, and ask yourself how easy it would be for you to actually apply them. Michele Boldrin and David Levine have rightly pointed out that "abstract, disembodied ideas have no value" (Boldrin and Levine 2008, p. 154). Only copies of the idea embodied in human or physical capital will have value, like when the ideas of Quantum mechanics are embodied in a scientist working for your company - a scientist whose human capital is of course a rival good. Ideas are always costly to learn and implement. If it was not so, societies would not need to spend significant shares of their GDPs to merely transmit freely available ideas such as Pythagoras' Theorem or the Periodic Table of Elements to millions of children each year.

\footnotetext{
${ }^{12}$ The World Trade Organization's Agreement on Trade-Related Aspects of Intellectual Property Rights (TRIPS) sets the minimum duration of these monopoly rights at 20 years for patents; while the Berne Convention for the Protection of Literary and Artistic works establishes that copyrights should last for at least the author's lifetime plus 50 years.
} 
The consequence of this is that there are sizeable economic rents that accrue to innovators in the absence of any intellectual property protection. Since ideas are not textbook non-rival goods, an innovator will always enjoy a first-mover advantage as it will be the sole supplier of the new product in question at least for some time. Copying and reverse engineering does take time and money, and they are worth the trouble only if the product being copied enjoys some degree of success (which of course implies that the innovator has already made some profits). Consumers who are impatient to get their hands on the new product will not wait for cheap copies to reach the market. And even when competitors arrive with cheaper alternatives to the market the innovator will enjoy the prestige and brand visibility from being the first, which should ensure her at least some additional profit.

Moreover, there exist several indirect financial benefits that innovators can reap even if they were to give away their ideas for free. Individual innovators will establish themselves as experts in their fields and will command high fees for their future services. Some innovative firms let people use their ideas freely and make profits by providing complementary services or by selling to other firms access to their customer base. A good example is Google, whose world-leading search engine can be used by anyone for free but has managed to make huge profits mainly from advertising.

Of course, the above arguments only say that some financial benefits exist in the absence of IPRs and therefore that some innovative activity will take place. Critics may argue that IPRs, by increasing the rewards to innovation, will lead to more ideas and therefore more growth. That conclusion, however, is far from being obvious since the protection of intellectual property through patents and copyrights entails important costs that ought to be considered as well.

A first and obvious cost, fully recognized in the economic growth literature, is the classical deadweight loss from monopoly pricing. For the duration of the monopoly rights, society will consume too little and pay too much for the innovation - whose diffusion will be retarded accordingly. 
But that is only the beginning. Technological progress itself will be hampered since an innovator can block the use of his idea by other innovators. This is of particular importance since, as emphasized by much of the endogenous growth literature, ideas enter into the production function of new ideas. Some of history's best-known patented inventions have been used in this way: James Watt was able to temporally block the development of better steam engines (notably that of Jonathan Hornblower) and Alexander Graham Bell was able to temporally block the development of better telephones (notably that of Thomas Alva Edison). ${ }^{13}$ This, incidentally, points to an additional social cost of intellectual property rights: bright minds such as Watt and Bell are diverted from innovation to rent-seeking.

Finally, we should not disregard the fact that intellectual property rights are costly to administer and even more costly to enforce. Their administration requires the establishment of a public bureaucracy where innovators will spend time and resources making their case. Their enforcement uses significant resources from the judicial system and demands large legal costs from both defendants and prosecutors. In some cases, like software and music piracy over the internet, the enforcement costs would be so high that governments just turn a blind eye to the practice - hardly a desirable outcome for otherwise law-abiding societies.

Because of all the above mentioned costs, society may end up worse off after introducing intellectual property rights - and it is not even guaranteed that innovative activity will increase. Douglas North has insisted that intellectual property rights should be beneficial since they increase the private marginal benefit of producing new ideas, moving the equilibrium towards the social optimum. ${ }^{14}$ The analysis comes straightforward from Arthur Cecil Pigou's seminal work on the effects of externalities in his classic The

\footnotetext{
${ }^{13}$ See Mokyr (1990, p. 88 \& 247) and Boldrin and Levine (2008, chapter 1).

14 "What determines the rate of development of new technology and of pure scientific knowledge? In the case of technological change, the social rate of return from developing new techniques had probably always been high; but we would expect that until the means to raise the private rate of return from developing new techniques was devised, there would be slow progress in producing new techniques. [...] Typically, innovations could be copied at no cost by others and without any reward to the inventor or innovator. The failure to
} 
Economics of Welfare (see, in particular, chapter 9 in Pigou 1932). It is easy to argue, however, that North's analysis is incomplete. While intellectual property rights may shift the private marginal benefit of innovation upwards, it is also the case that they move the social marginal benefit of innovation downwards: every new idea is less socially-beneficial due to the monopoly pricing, rent-seeking and cost of enforcement problems mentioned above. If these two curves are moving then Pigou's framework no longer gives an unambiguous answer; social welfare may well end up decreasing. ${ }^{15}$

\subsection{Empirical arguments}

All of the above should lessen our confidence on the general theoretical argument for intellectual property rights as beneficial - let alone essential for innovation and growth. While theoretical arguments apply to any time and place, additional arguments can be put forward against the idea that IPRs were a major explanatory factor of the Industrial Revolution.

Innovation in pre-industrial times did not involve the million-sized R\&D budgets of today's major corporations. Economic historians have long sustained that small and incremental innovations sum up to most of the efficiency gains during the Industrial Revolution (Jones 1981, Rosenberg 1982, Mokyr 1990). Human ingenuity was the main element; as Joel Mokyr put it: "A typical innovator in those years was a dexterous and mechanically inclined person who became aware of a technical problem to be solved and guessed approximately how to go about solving it." (Mokyr 1990, p. 83-84). Such innovations take place through learning by doing, and the relatively modest financial costs they required were likely to be covered by the rents

develop systematic property rights in innovation up until fairly modern times was a major source of the slow pace of technological change." (North 1981, p.164).

${ }^{15}$ Interestingly, Pigou himself did not believe that intellectual property rights would foster innovation; although for different reasons: "The patent laws aim, in effect, at bringing marginal private net product and marginal social net product more closely together. By offering the prospect of reward for certain types of invention they do not, indeed, appreciably stimulate inventive activity, which is, for the most part, spontaneous, but they do direct it into channels of general usefulness." (Pigou 1932, p. 185). 
that accrue to an innovator in the absence of any intellectual property protection.

Accordingly, there is considerable evidence against the idea that intellectual property rights played a major role in the Industrial Revolution. Patents were not invented in England with the Statute of Monopolies of 1623, they existed in the Netherlands since the 16th century and in northern Italy since the 15th century - begging the question of why they did not foster an Industrial Revolution there. Moser (2004, 2005) has analyzed all innovations presented at the World Fairs of 1851 and 1876 and has shown that only $11 \%$ of British inventions and $14 \%$ of American ones were patented. Even more telling, countries with no patent laws (Switzerland and Denmark in 1851, Switzerland and the Netherlands in 1876) did not have less innovations per capita and had a disproportionately large share of the medals awarded in these fairs to the best innovations.

As argued by Mokyr (2009), patents may have played a role in the imaginary of would-be innovators but the reality was different. During the Industrial Revolution the cost of obtaining a patent were very high in England: the equivalent of 37,000 US dollars of the year 1998 (Lerner 2000). Patents were also difficult to enforce, and doing so implied large additional costs. The consequence was that few innovators actually profited from the patent system at the time. A good proof of this is that the English Parliament felt contrived to offer awards and pensions to some of the best-known innovators of the Industrial Revolution despite the fact that they had obtained patents (Mokyr 2009).

Turning our attention to developing countries nowadays, the case for the importance of intellectual property rights is equally problematic. Most of the world's innovation is carried out in the developed world, and developing countries gain from imitating and coping these ideas. Intellectual property rights would only hinder this process by prohibiting developing countries 
from using these ideas or forcing them to pay fees to the patent holders in developed nations.

Of course, there are many additional mechanisms that can come into play. For instance, in the absence of intellectual property rights in developing countries some ideas that are only useful for them may not get produced (Diwan and Rodrik 1989). There is a large theoretical literature on the subject and the results concerning the overall effect of intellectual property rights in developing countries tend to be ambiguous. ${ }^{16}$ Our aim here is not to resolve the ambiguities of this literature but simply to point out that a policy that is so difficult to prove as unambiguously beneficial for developing countries should not be regarded as a likely explanation of the large gap between them and developed nations.

Note as well that the World Trade Organization's TRIPS agreement, responsible for the introduction of intellectual property rights throughout the developing world, was promoted exclusively by the United States, Europe and Japan and was consistently opposed by numerous developing nations notably Brazil, India, South Korea and Mexico. ${ }^{17}$ Do we really believe that developing country governments are so obtuse that they would uniformly oppose a piece of legislation that was beneficial for them? The case of China, both the fastest-growing developing country of the last two decades and a notorious infringer of intellectual property rights, should convince us that at the very least - rapid economic development can perfectly take place in the absence of strong protection of intellectual property.

To sum up, a large range of theoretical and empirical arguments can be invoked against the idea that intellectual property rights are essential for economic growth and, with even more force, against the idea that they played a large role in the advent of the Industrial Revolution.

\footnotetext{
${ }^{16}$ See, inter alia, Deardorff (1992), Helpman (1993), Lai and Qiu (2003), Angeles (2005), Parello (2008) and Dinopoulos and Segerstrom (2010).

${ }^{17}$ For a detailed account of TRIPS' negotiating history see Gervais (2003).
} 


\section{Conclusions}

This paper has argued at length that the current emphasis on property rights as a fundamental driver of economic development may be overstated. Property rights have become a widely accepted answer to the questions of why the Industrial Revolution took place in the western world and why so many developing countries still lag behind the rich ones. The current intellectual climate favours institutional engineering, and could distract us from alternative lines of research.

The core of our arguments have been shaped in two parts. First, we have argued that the case for the importance of property rights on capital accumulation, while theoretically sound, lacks empirical support. There is solid evidence that property rights were respected in pre-industrial Europe: low rates of return on private capital, episodes of rapid investment in new forms of physical capital, and well-documented difficulties that kings faced for raising taxes or expropriating their subjects. As for the developing world we can at least point out that real interest rates are on average similar to those of developed countries.

Second, we have argued that the case for the importance of property rights on the production of ideas can be challenged both on theoretical and empirical grounds. On the theory side, we have argued that innovations can take place in the absence of intellectual property rights and that the introduction of such rights, while raising the rents of current innovators, creates important costs for society and for would-be innovators. On a purely theoretical basis, intellectual property rights can be proved detrimental without much trouble. The empirical evidence further weakens the case for the importance of intellectual property rights in pre-industrial Europe or in today's developing world. Research has shown that most innovations were not patented in pre-industrial Europe, that countries without a patent system innovated as much as those that did have one and that most innovations during this period were small and incremental - and would take place irrespective of the patent system. The case may be even less favorable for the 
developing world, where large gains can be expected from freely imitating the stock of ideas from the developed world rather than having to pay for it. Developing countries' own attitudes can be taken as evidence of revealed preferences against intellectual property protection.

While we do believe that the case for property rights has been overstated, it is not our intention to portray institutions in general as unimportant. In their broadest sense, such as those given by Douglass North and Avner Greif in the definitions transcribed in section 2 of this paper, institutions must be important. The challenge, however, is to determine what specific institutions are important and whether any of them could satisfactorily explain phenomena such as the Industrial Revolution or the gulf between rich and poor countries. This paper has analyzed the evidence for one such specific institution, property rights protection, and has found it wanting.

A more modest hypothesis for the role of institutions in economic development would be that particular countries at a particular time may be significantly affected by specific institutional arrangements - which differ from case to case. Institutions may be important in some cases, but no single institutional structure can explain economic development (or lack of it) throughout the world. As it turns out, surprisingly strong evidence for this more limited role of institutions can be found in the literature. Examples of papers analyzing the consequences of concrete institutional arrangements in clearly circumscribed areas include Banerjee and Iyer (2005) on revenue collection in different districts of colonial India, Dell (2010) on the mita labour system in the highlands of Peru and Berger (2009) on tax policy in colonial Nigeria. Contrary to the cross-country literature cited in the introduction, these papers do not aim to prove that institutions are the ultimate source of economic growth everywhere and every time. Instead, they provide convincing evidence that particular institutional arrangements may have sizeable long-term consequences in particular areas such as bureaucratic capacity, health, education and household consumption.

To this more modest approach of institutional analysis we can subscribe. 
Institutions have their place in explanations of growth and development but their form should be made explicit for each time and place and we should not expect the same institutional explanation to fit all cases. 


\section{References}

Acemoglu, D., Johnson, S. and Robinson, J. A. 2001, The colonial origins of comparative development: an empirical investigation, American Economic Review 91 (5), p. 1369-1401.

Acemoglu, D., Johnson, S. and Robinson, J. A. 2002, Reversal of Fortune: Geography and Institutions in the Making of the Modern World Income Distribution, Quarterly Journal of Economics 117 (4), p. 1231-1294.

Acemoglu, D., Johnson, S. and Robinson, J. A. 2005, Institutions as a fundamental cause of long run growth, in: Aghion, P. and Durlauf, S. (eds.), Handbook of Economic Growth, Volume 1A, Chapter 6, Elsevier.

Angeles, L. 2005, Should developing countries strengthen their intellectual property rights?, The Berkeley Electronic Journal in Macroeconomics - Topics, vol. 5 (1), article 23.

Angeles, L. 2007, Income Inequality and Colonialism, European Economic Review 51 (5), 1155-1176.

Angeles, L. 2010, Institutions and Economic Development. New tests and new doubts, Discussion Paper 2010-03, Department of Economics, University of Glasgow.

Angeles, L. and Neanidis, K. 2009, Aid Effectiveness: The Role of the Local Elite, Journal of Development Economics 90 (1), 120-134.

Angeles, L. and Neanidis, K. 2010, Colonialism, Elite Formation and Corruption, Discussion Paper 144, Economics, University of Manchester.

Banerjee, A. and Iyer, L. 2005, History, institutions and economic performance: the legacy of colonial land tenure systems in India, American Economic Review 95, p. 1190-1213.

Berger, D. 2009, Taxes, institutions and governance: evidence from colonial Nigeria, mimeo, New York University.

Boldrin, M. and Levine, D. K. 2008, Against Intellectual Monopoly, Cambridge: Cambridge University Press.

Campbell, J. Y., Diamond, P. A. and Shoven, J. B. 2001, Estimating the real rate of return on stocks over the long run, papers presented to the Social Security Advisory Board, downloaded at 
http://www.ssab.gov/Publications/Financing/estimated\%20rate\%20of\%20return.pdf , 10 March 2010.

Caselli, F. 2005, Accounting for Cross-Country Income Differences, in: Aghion, P. and Durlauf, S. (eds.), Handbook of Economic Growth, Volume 1A, Chapter 9, Elsevier.

Clark, G. 1996, The political foundations of modern economic growth: England 1540-1800, Journal of Interdisciplinary History 26 (4), 563-588.

Clark, G. 2007, A Farewell to Alms, Princeton: Princeton University Press.

Conklin, J. 1998, The theory of sovereign debt and Spain under Philip II, Journal of Political Economy 106 (3), p. 483-513.

Deardorff, A. V. 1992, Welfare effects of global patent protection, Economica 59, p. 35-51.

Dell, M. 2010, The mining mita: explaining institutional persistence, forthcoming in Econometrica.

Dincecco, M. 2009, Fiscal Centralization, Limited Government and Public Revenues in Europe, 1650-1913, Journal of Economic History 69 (1), p. 48-103.

Dinopoulos, E. and Segerstrom, P. 2010, Intellectual property rights, multinational firms and economic growth, Journal of Development Economics 92 (1), p. 13-27.

Dittmar, J. 2010, Information technology and economic change: the impact of the printing press, mimeo.

Diwan, I and Rodrik, D. 1989, Patents, appropriate technology and North-South trade, The World Bank, working paper 251.

Drelichman, M. and Voth, H. J. forthcoming, Serial defaults, serial profits: returns to sovereign lending in Habsburg Spain, 1566-1600, Explorations in Economic History.

Easterly, W. and Levine, R. 2003, Tropics, germs and crops: how endowments influence economic development, Journal of Monetary Economics 50, 3-39.

Epstein, S. R. 2000, Freedom and growth. The rise of states and markets in Europe, 1300-1750, Routledge Explorations in Economic History, volume 
17, Routledge: London and New York.

Epstein, S. R. 2005, 'The rise of the West', in J. Hall and R. Schroeder (eds.), An Anatomy of Power: The Social Theory of Michael Mann, Cambridge University Press.

Feyrer, J. and Sacerdote, B. 2009, Colonialism and Modern Income: Islands as Natural Experiments, The Review of Economics and Statistics 91(2), 245-262.

Gervais, D. 2003, The TRIPS Agreement, Drafting History and Analysis, London: Sweet \& Maxwell.

Glaeser, E. L., La Porta, R., Lopez de Silanes, F. and Shleifer, A., 2004, Do Institutions cause growth?, Journal of Economic Growth 9, 271-303.

Greif, A. 2006, Institutions and the Path to the Modern Economy: Lessons from Medieval Trade, Cambridge University Press.

Hall, R. E. and Jones, C. I. 1999, Why do some countries produce so much more output per worker than others?, Quarterly Journal of Economics 114, 83-116.

Hansson, G. 2009, What determines rule of law? An empirical investigation of rival models, Kyklos 62 (3), 371-393.

Helpman, E. 1993, Innovation, imitation and intellectual property rights, Econometrica 61 (6), p. 1247-1280.

Homer, S. 1963, A History of Interest Rates, Rutgers University Press: New Brunswick and New Jersey.

John Hampden Society, 2009, Newsletter of the John Hampden Society No. 58 (Spring 2009).

Jones, E. L. 1981, The European Miracle, Cambridge: Cambridge University Press.

Knack, F. and Keefer, P. 1995, Institutions and economic performance: cross-country tests using alternative measures, Economics and Politics 7, 207-227.

Lai, E. L.-C. and Qiu, L. D. 2003, The North's intellectual property rights standard for the South?, Journal of International Economics 59 (1), p. 183-209.

Langdon, J. 2004, Mills in the medieval economy. England 1300-1540, 
Oxford University Press.

Lerner, J. 2000, 150 years of patent protection, NBER working paper n. 7478 .

Marshall, M. G. and Jaggers, K. 2009, Polity IV Project: Dataset Users' Manual.

Mokyr, J 1990, The lever of riches, Oxford: Oxford University Press.

Mokyr, J. 2009, Intellectual Property Rights, the Industrial Revolution, and the begginnings of modern economic growth, American Economic Review Papers and Proceeding, 99 (2), p. 349-355.

Moser, P. 2004, Determinants of Innovation. Evidence from 19th century world fairs, Journal of Economic History 64 (2), p. 548-552.

Moser, P. 2005, How do patent laws influence innovation? Evidence from Nineteenth-century world's fairs, American Economic Review 95 (4), p. $1214-1236$.

North, D. C. 1981, Structure and change in economic history, New York: W. W. Norton \& Co.

North, D. C. 1990, Institutions, Institutional Change and Economic Performance, Cambridge: Cambridge University Press.

North, D. C. 2005, Understanding the process of economic change, Princeton: Princeton University Press.

North, D. C. and Thomas, R. P. 1973, The rise of the western world: A new economic history, Cambridge: Cambridge University Press.

North, D. C. and Weingast, B. R. 1989, Constitutions and Commitment: The evolution of institutions governing public choice in seventeenth-century England, The Journal of Economic History 49 (4), 803-832.

Olson, M. 2000, Power and Prosperity. Outgrowing communist and capitalis dictatorships, Basic Books.

Paldam, M. and Gundlach, E. 2008, Two views on Institutions and Development: The Grand Transition vs the Primacy of Institutions, Kyklos 61 (1), 65-100.

Parello, C. P. 2008, A north-south model of intellectual property rights protection and skill accumulation, Journal of Development Economics 85 (1-2), p. 253-281. 
Pigou, A. C. 1932, The Economics of Welfare, London: Macmillan.

Przeworski, A. 2004, The last instance: Are institutions the primary cause of economic development?, European Journal of Sociology 45(2): 165188.

Quinn, S. 2001, The Glorious Revolution's effect on private finance: a microhistory, 1680-1705, Journal of Economic History 61 (3), 593-615.

Reinhart, C. and Rogoff, K. 2009, This time is different, Princeton: Princeton University Press.

Rodrik, D., Subramanian, A. and Trebbi, F. 2004, Institutions rule: the primacy of institutions over geography and integration in economic development, Journal of Economic Growth 9, 131-165.

Romer, P. M. 1986, Increasing returns and long-run growth, Journal of Political Economy 94, 1002-37.

Romer, P. M. 1990, Endogenous Technological Change, Journal of Political Economy 98, S71-S102.

Rosenberg, N. 1982, Inside the Black Box: Technology and Economics, Cambridge: Cambridge University Press.

Solow, R. M. 1956, A Contribution to the theory of Economic Growth, Quarterly Journal of Economics 70, 65-94.

Van Zanden, J. L. 2009, The long road to the Industrial Revolution, Global Economic History Series, volume 1. Brill: Leiden and Boston.

World Bank, 2009, World Development Indicators. Downloaded at http://data.worldbank.org/datacatalog/world-development-indicators . 
Figure 1

Real interest rates and GDP per capita around the world, 1980-2008

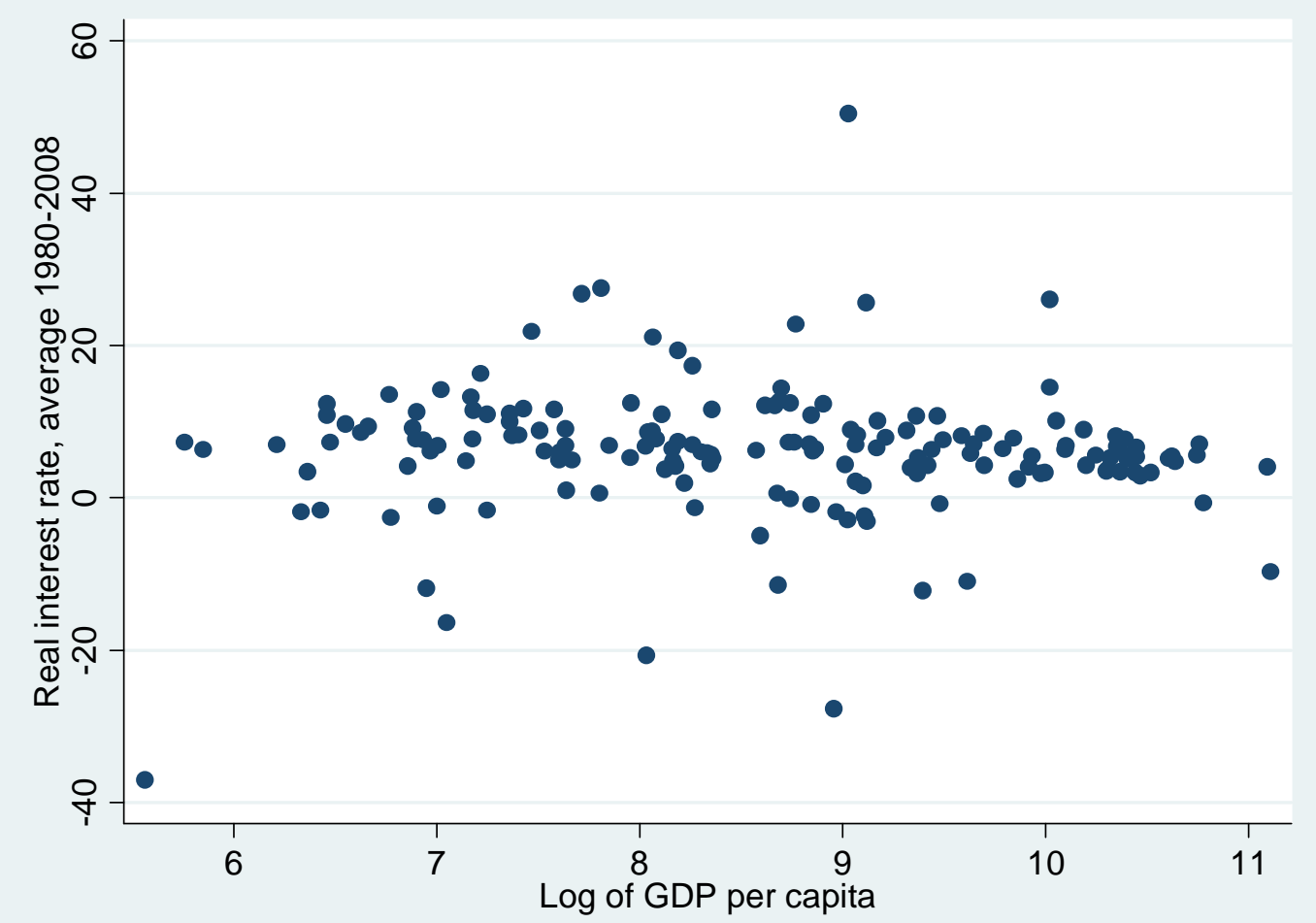

Source: World Bank (2009). 